\title{
Human Integration of a Character-based Curriculum and Humanistic Values As Basic Initiation of a Human Rights-friendly School
}

\section{S. Wahjusaputri}

Educational Administration, Graduate School of Prof. DR. HAMKA Muhammadiyah University, Jalan Warung Buncit No. 17 Street, Pancoran, South Jakarta 12790

\section{Abstract}

A Human Rights-Friendly School is founded where human rights are learned, taught, practiced, respected, protected, and promoted. A qualitative approach was taken and the study used thematic analysis of key concepts and codes. The study aims to build the capacity of the whole school community by promoting a democratic environment, innovative teaching methods, and responsible citizenship. From the

Corresponding Author:

S. Wahjusaputri

sinthaw@uhamka.ac.id

Received: 6 April 2018

Accepted: 3 May 2018

Published: 26 July 2018

Publishing services provided by Knowledge E

(c) S. Wahjusaputri. This article is distributed under the terms of the Creative Commons

Attribution License, which permits unrestricted use and redistribution provided that the original author and source are credited.

Selection and Peer-review under the responsibility of the ISLLE 2017 Conference Committee.

\section{G OPEN ACCESS} way decisions are made in schools, to the way people treat each other, to the curriculum and extracurricular activities on offer, right down to the very surroundings in which students are taught, the school becomes an exemplary model for human rights education.

Keywords: character-based curriculum, humanistic values, human rights-friendly school

\section{Introduction}

The international community has repeatedly stressed the importance of human rights education as an essential tool for promoting respect, participation, equality, and nondiscrimination, as well as stable and harmonious relations among communities, mutual understanding, and peace. This consensus has led to the adoption of various intergovernmental frameworks aimed at encouraging the development of relevant national strategies and programs. Ministries of education or equivalent institutions have a major responsibility for ensuring national implementation in close cooperation with all stakeholders [1].

A Human Rights-Friendly School places human rights at the heart of the learning experience and makes human rights an integral part of everyday school life. Ministries of education or equivalent institutions have a major responsibility for ensuring national implementation in close cooperation with all stakeholders. From the way decisions are 
made in schools, to the way people treat each other, to the curriculum and extracurricular activities on offer, right down to the very surroundings in which students are taught, the school becomes an exemplary model for human rights education [2].

Images of education in Indonesia in the last five years the phenomenon of violence, bullying, drugs, and other issues that lead to violations of human rights in education, especially school rifer, either directly or indirectly, and performed not only by the school as an institution of educational workers through teachers and education personnel, but also by the students themselves. And the school has embraced human rights not only inside the classroom, but also as an integral part of its clubs and extracurricular activities; a human rights garden maintained by students and staff is just one space where openness, tolerance, and debate are promoted. From the results of the study disciplines and approaches, there seems to be common ground that all sorts of crisis stem from moral crisis (character) or the moral crisis. Here a holistic adhesive is required to glue all other education programs together in order to implement and internalize the values of human rights as a whole, which further provides the foundation and direction for the character development efforts of the nation through education [3]. The study based on phenomenon, then school can develop a more humanistic management approach: (a) Improve human relations between teacher and student, teacher and teacher, student and student etc.; (b) Help develop a good attitude in students and teachers as well, e.g. co-operation, mutual respect; (c) Facilitate healthy emotional development in students; (d) Facilitate socialization through participation in interactive and co-operative learning activities; (e) Improve students' discipline and moral behavior; (f) Develop creativity both in students and teachers; $(g)$ Improve standard of quality of teaching and learning [1].

The goal of a study about a human rights-based approach to education is simple: to guarantee every child a quality education that respects and promotes her or his right to dignity and optimum development. Achieving this goal is, however, enormously more complex. Overall only a small proportion of school students are able to take up the opportunities available in the curricula to learn about human rights. Therefore, in the context of the new national curriculum now available in schools, there is a need to refocus efforts to ensure that Indonesian school students are given the opportunity to learn and engage in discussions about a range of human rights issues as part of their school experiences, throughout their school years. 


\section{Methods}

This study was based on a pragmatic philosophical research paradigm whose approach applies pluralistic means of acquiring knowledge about a phenomenon [4]. It was an analytical and explorative study and both primary and secondary data, generated through interviews, workshops, observation and textbook analysis, were used. A qualitative approach was taken and the study used thematic analysis of key concepts and codes. According to Berg, most researchers have at least one methodological technique they feel most comfortable using, which often becomes their favorite or only approach to research [5].

The author makes a mindset Friendly Schools applicable human rights in Elementary, Intermediate and SMA/SMK. Based on interviews with one member of the Human Rights Commission, Mr. Dr. Manager Nasution in June 2017. Looking at the phenomenon that occurs, the authors suggest the solution that the Human Rights-Friendly Schools should provide direction for character education and humanistic values through learning materials (human rights as and in education), civilizing values of human rights through the whole process of education (human rights education trough) and the educational environment as a whole (holistic approach).

\section{Results}

The mobilization of the community may bring many benefits, including providing funds for the construction of classrooms and sanitation facilities, providing food, offering paid and unpaid labor for building school structures, planting trees, sourcing land, and supplying locally procurable materials among other duties [6]. Years of research on the contribution of learning environments to students' learning achievement and development have led to a general recognition that, beyond students' own innate abilities, motivation, and prior knowledge, learning occurs when systems of the home, community, schools, and peers come together to form a protective circle that nurtures and develops students' growth [7].

The discipline of social sciences and humanities in the Indonesian school curriculum encompasses five subject areas: equity studies, family studies, general social sciences, philosophy, and world religions. Although these subject areas are very different from one another, they all systematically explore the ways in which individuals influence and are influenced by families, communities, cultures, institutions, and societies, and by ideas, norms, and values (DIKNAS). Effective learning in all subjects of the social 
sciences and humanities curriculum in Indonesia depends on the development of skills and understanding in four areas: (1) Disciplined Inquiry and Critical Literacy: Social sciences and humanities courses focus on the use of disciplined, structured inquiry to understand human beings, human behavior, and human nature; (2) Problem Solving: Social sciences and humanities courses require students to engage actively in solving problems faced by individuals, families, diverse groups, institutions, and societies; (3) Understanding of Self and Others: Students in social sciences and humanities courses are provided with rich opportunities to enhance their self-understanding and understanding of others through an examination of their personal belief systems and also of the foundations and implications of different viewpoints and lived experiences of others; (4) Local and Global Mindedness: Social sciences and humanities courses develop students' awareness that people do not live in isolation; each person affects and is affected by his or her social, cultural, economic, and environmental context (Table 1).

TABLE 1: Researchs Road Map.

\begin{tabular}{|c|c|c|}
\hline No. & Years & Detail \\
\hline 1 & 2011 & $\begin{array}{l}\text { Research Plan Indonesia found cases in Bogor } \\
\text { involving } 300 \text { students, including: } 15.3 \% \text { of } \\
\text { elementary students, } 18 \% \text { of junior high school } \\
\text { students, and } 16 \% \text { of senior high school/vocational } \\
\text { school students, both teachers ( } 14.7 \%) \text { and conducted } \\
\text { by fellow friends ( } 35.3 \%) \text {. }\end{array}$ \\
\hline 2 & 2012 & $\begin{array}{l}\text { Plan Indonesia and the International Center for } \\
\text { Research on Women (ICRW) again conducted research } \\
\text { with results showing that } 84 \% \text { of children in Indonesia } \\
\text { experience violence in schools. }\end{array}$ \\
\hline 3 & 2013 & $\begin{array}{l}\text { The Indonesian Child Protection Commission (KPAI) } \\
\text { released its survey results of 1,026 student } \\
\text { respondents indicating that } 87.6 \% \text { of children claimed } \\
\text { to have experienced school violence in various forms, } \\
\text { of which } 29.9 \% \text { of the violence was committed by } \\
\text { teachers, } 42.1 \% \text { by classmates and } 28.0 \% \text { by friends } \\
\text { from other classes. }\end{array}$ \\
\hline 4 & $2014-2015$ & $\begin{array}{l}\text { Komnas HAM also noted that it received at least } 54 \\
\text { filed complaints related to alleged violations of the } \\
\text { rights of children, which increased in } 2015 \text { to } 57 \\
\text { complaint files. }\end{array}$ \\
\hline
\end{tabular}

Human Rights-Friendly Schools are inclusive environments where all are encouraged to take active part in school life, regardless of status or role, and where cultural diversity is celebrated. Through an approach that goes beyond the classroom and into all aspects of school life, commonly called a "whole-school approach," both schools and young people become powerful catalysts for change in their wider communities. The international community has repeatedly stressed the importance of human 
rights education as an essential tool for promoting respect, participation, equality, and nondiscrimination, as well as stable and harmonious relations among communities, mutual understanding, and peace. This consensus has led to the adoption of various intergovernmental frameworks aimed at encouraging the development of relevant national strategies and programs.

\subsection{Human rights-friendly schools}

Center for Curriculum Redesign (CCR) states that friendly schools in the concept of human rights, human rights education (human rights education/HRE) serves as the material taught and as a method or approach to implement or practice the values of human rights in schools [8]. This approach seeks to build a human rights culture in schools through the learning process, real action, and respect for others, provide protection to all residents of schools, and disseminate human rights. Gardner says that school characteristics are expected to be created through the application of the Human Rights-Friendly Schools concept, namely: (a) the creation of a school environment that is able to apply the values of equality, nondiscrimination, respect, participation, and respect for human dignity; (B) the existence of a conducive atmosphere for the later development of democratic values; (C) measures to empower teachers, students, noneducational personnel, and occupants of other schools to participate in making and implementing school policies; (D) concern for improving empathy among the inmates of the school so that there is solidarity and shared responsibility to provide the best for the school; (E) measures to encourage students to think critically and discuss in dealing with human rights issues and other problems that they face every day; (F) an attempt to carry out enrichment in the learning and experience of human rights inside and outside the classroom [9].

\subsection{Character building}

Character education by Davidson, Lickona, and Khmelkov was "Throughout history, and in cultures all over the world, education rightly conceived has had two great goals: to help them become good, which means that throughout history and in cultures around the world, properly conceived education has had two major objectives, namely to help students become better [10]. The CCR state that "[c] haracter education is about the acquisition and strengthening of virtues (qualities), values (ideals and concepts), and the capacity to make wise choices for a well-rounded life and a thriving 
society" [8]. Character education is based on recovery and strengthening of good (quality), values (ideals and concepts), and the ability to make wise choices for the life of a knowledgeable and growing community. The CCR say that the broad goals of character education are: (a) to build a foundation for lifelong learning (to build a foundation for lifelong learning); (b) to support successful relationships at home, in the neighborhood, and in the workplace (to support successful relationships at home, in the community, and in the workplace); (c) to develop personal values and virtues for ongoing participation in a global world (to develop personal values and virtues for sustainable participation in a global world) [8]. Lickona describes some of the reasons for character education, including: (1) the number of young people who hurt each other because of the lack of awareness of moral values; (2) providing moral values for the younger generation is one of the most important functions of civilization; (3) the role of the school as an educator of character becomes increasingly important as many children obtain some moral teachings from parents, community, or religious institutions; (4) the moral values that are universally received are attention, trust, respect, and responsibility; (5) democracy has a special need for moral education because democracy is the regulation of, for, and by the community; (6) there is nothing such as a value-free education [11]. Schools teach value-free education. Schools teach values every day either by design or not.

\subsection{Curriculum humanistic values}

Curriculum humanistic values are offered by educational humanistic experts in response to the academic curriculum. A highly oriented academic curriculumthe mastery of the material by placing learners as objects in education, while positioning the humanistic curriculum learners as subjects and directing education toward integral human development [12]. Humanistic education is an oriented education model and views humans as humans (humanization), namely God's creatures by nature. A humanistic-based education is expected to restore the role and function of the human being, which is to return man to nature as well as well-being (Khairu umma). According to a CCR (Center for Curriculum Redesign), a holistic approach needs to be redesigned to offer a framework for curriculum development with a humanistic values educational dimension that is full of knowledge (knowledge), skills (skills), character (character), and metacognition (metacognition) [8]. 


\section{Conclusion}

From the decisions are made in the schools, to the curriculum and extracurricular activities on offer, right down to the very surroundings in which students are taught in, the school becomes an exemplary model for human rights education. Knowledge must maintain a better balance between traditional and modern subjects as well as interdisciplinary. Skills related to the use of knowledge and engage in feedback with knowledge. The character qualities describe how a person relates to and behaves in the world.

\section{Acknowledgement}

Authors would like to thank Graduate School of Prof. DR. HAMKA Muhammadiyah University for facilitated this research.

\section{Conflict of Interest}

Authors declare that there is no conflict of interest in this research.

\section{References}

[1] UNESCO, UNICEF: A Human Rights-Based Approach to Education for All. New York: UNICEF. 2007.

[2] UNESCO: Learning the Way of Peace. A Teacher Guide to Peace Education. New Delhi: UNESCO Publisher. 2001.

[3] Muhaimin: Pengembangan Kurikulum Pendidikan Agama Islam. Jakarta: Raja Grafindo Persada. 2005.

[4] Morgan D: paradigms lost and paradigms regained: methodological implications of combining qualitative and quantitative methods. J Mixed Res. 2007; 1(1): 48-76.

[5] Berg BL: Qualitative Research Methods For The Social Science, Fourth Edition. Boston: A Pearson Education Company. 2001.

[6] UNICEF: Child Friendly Schools Manual. New York: UNICEF. 2009.

[7] Rwanda Ministry of Education: Child Friendly School Infrastructure Standards and Guidelines: Primary and Tronc Commun Schools. Unpublished Document. 2009.

[8] Center for Curriculum Redesign (CCR): Education for the 21st Century: What should students learn?. Boston: Center for Curriculum Redesign. 2015. 
[9] Gardner H: Five Minds for the Future. Boston: Harvard Business Review. 2009.

[10] Davidson M, Lickona T, Khmelkov V: Smart \& Good Schools: A New Paradgim for High School Character Education. In the Handbook of Moral and Character Education. London: Routledge. 2008.

[11] Lickona T: Educating for Character: How Our Schools Can Teach Respect and Responsibility. New York: Bantam Books. 1992.

[12] Sukmadinata NS: Pengembangan Kurikulm: Teori dan Praktik. Bandung: PT Remaja Rosdakarya. 1997. 